\title{
STUDENT USE OF THE LIBRARY
}

\author{
By Ellen P. Campbell
}

Ever since Miss Campbell came to the Rutgers Library eigbt years ago, sbe bas been one of the civilizing influences of the campus. Sbe welcomes all students who come to the Library to study, she passes quietly by those who bave peacefully fallen asleep over their books, but woe be unto the freshman or senior-or even the white-beaded professor-wbo uses the Reading Room for a social center. Sucb nuisances are told politely but very firmly that otber places are provided for their conversations. Perbaps it is partly on account of ber zeal that the Library is overfilled with those who want to study.

T EIGHT o'clock, six mornings a week, the Rutgers Li-
brary staff is ready to serve the students of the Univer-
sity who, in an unending stream, pass through the doors of the building until eleven at night. Some go straight to the Reserve Desk to get books for their assigned readings; others hurry for the morning papers; still others go to the periodical shelves. The commuters come, bringing their texts, to study until their first classes are held; while the students in residence are more than likely to withdraw books from the Library for use in their rooms.

Not only is the Library used constantly all day long, but the use is by an unusually large number of the student body. During the session of $1936-37,98.5 \%$ of the senior class, and $92 \%$ of the entire student body, withdrew books for home use. The next year, $1937-38,98 \%$ of the senior class and $92.6 \%$ of the whole student body took books out of the Library. If the $7.4 \%$ of the student body not using the Library were investigated, it would probably be found that each had access to other collections of books more conveniently located, as the agricultural students may use the library on the College Farm campus entirely, and the ceramic students perhaps use only the books that are located in their building.

The year $1937-38$ was the first one in which there were not enough chairs in the Library to accommodate the students who wanted to read and study. At least during one period of each week every available chair was used. Students were found at desks of the Library staff, in private offices, and sometimes on 
the stairs to the book stacks. A few left the Library rather than study in these unconventional places, but most accepted chairs in odd corners in order to study. The seating capacity of the reading room is $I_{3} 8$. There have been mornings when over $I_{4} 0$ young men have been studying in the Reading Room at one time. The same crowded situation is found in the study cubicles of the book stacks. These conditions have been gradually developing for some years. When the new gymnasium was finished, a member of the faculty said that we would have fewer students in the Library because they would prefer to go to the gymnasium to play. When the Student Union building was opened a year ago the same idea was expressed, and, since it is as accessible as the Library, it seemed possible that this would be the case. But the Library still looks for more chairs.

If we could keep a record of the use of current periodicals, it would be found unbelievably large. No matter how often we straighten up the tables in the Reading Room, there are still dozens of magazines to be put away. Certain titles are always found in use. Among these Life, Time, Fortune, American Pbotograpby, The New Republic, and The Nation are especially popular. Perhaps English humor is peculiar to that nation; but the Rutgers student body also likes the variety found in Punch, if one may judge from the number of issues left on the tables.

The daily newspapers and the magazines dealing with current affairs seem to be in more demand than they have been, with depression, recovery and recession, and the activities of foreign nations stimulating the interest of the students. It has been said that if the comic pages and the sports pages were removed from the papers there would be small demand for what was left. Observers in the Reading Room notice, however, that while the sports page still plays a large part in the reading interest of the student, the entire paper is read: editorial, drama, literary criticism, as well as the news of the day. The students "reserve" the papers from each other. This system of "reserving" the paper is interesting: a student will ask for the paper after the person who is reading it is through, another will make the same request of the second, and so on, until four or five students are waiting for the same paper. We now have two copies of the morning papers available, but even with the extra copies, some students have to go to class without seeing them. 
For the aid of the students, about six thousand books and periodicals are placed on the reserve shelves each semester. The classes have assigned readings in these volumes, and the books are issued for use in the Library. During a usual day, over three hundred and fifty books are given to students, but, when there are tests or examinations, this number is increased to five hundred volumes. In one unusual instance, in the four days before a freshman test, thirty copies of one title were issued I 300 times.

An unusual feature of the lending of books by the Library is that no fines are charged and no provision is made in the circulation of books for fines. We experience very little trouble in getting books returned when they are wanted. Most of the students are known to the desk assistants, and if the written notice does not bring immediate response, the borrower is spoken to personally. We feel that in this way a more friendly atmosphere is created, and the results are satisfactory. We ask the students to clear their accounts periodically. If any one of them does not return all books at that time, his grades for the semester are withheld until he meets the requirements of the Library. With very few exceptions, all student accounts are cleared.

The Library is used chiefly by three classes of borrowers: (I) the undergraduates who are enrolled in the colleges for men of Rutgers; (2) the students from the New Jersey College for Women; and (3) the in-service teachers who register in the Educational Extension courses.

A recent study of the types of books withdrawn from the Library shows that about $50 \%$ of the entire enrollment of the Women's College withdrew books from the Main Library. Of these $30 \%$ were taken from the language and literature section. Music was second in the number of books withdrawn with Io\%. Economics, history, philosophy, psychology, and art follow in the order named. The students of this College have a library of over 65,000 volumes on their own campus and the number of book withdrawals from that Library is not included.

The Educational Extension students are primarily interested in literature on the methods of teaching, school administration, and so forth. Thirty-seven per cent of their total withdrawals are of books from the Education section of the Library. Litera- 
ture is second, with $14.5 \%$, and philosophy, psychology, and allied subjects third with $9 \%$. The next four subjects which these students take from the Library are history, economics, sociology, and the sciences. It should be remembered in considering these percentages that the borrowers come from all over the state, and it is more than likely that they get many books from their town libraries. By far the largest number of withdrawals are made by the colleges for men.

The use of books from the Library has steadily increased. For the months of January and February I938, the average withdrawal of books for home use, not including periodicals and government material, was 228 a day. This is $33 \%$ increase over the books taken from the Library six years ago. A four-day sampling of the students who withdrew books from the Library shows that $5.2 \%$ of the entire enrollment took one or more books out each day.

One of the most pleasant activities of desk work is helping students find information on subjects in which they are interested. Often these are connected with class work, but frequently they represent the outside interests of the students - from stuffing animals to repairing automobiles-as many varieties of subjects as there are interests. This is about the best way to learn to know the students, particularly the shy ones. The students, as a whole, are courteous both in their conduct and in their speech. At times they seem thoughtless, but when this is mentioned to them, they are surprised and point out that they have been misunderstood. They are, indeed, inventive and able to rise to any occasion. An English major asked for a play called "Public Enemy." After a little questioning it was discovered that he wanted Ibsen's "Enemy of the People" and not a gangster play. We felt pleased that we were able to find what he wanted, but he apparently thought that we had been a little slow in meeting a request so obvious. When an upper classman asked for the second volume of a man named King, and we gave him Kings $I I$ in the Bible, he did not bat an eye, but took the Bible and prepared the work assigned him.

We hope, and it looks as if we have reason to believe, that the use of the Library will increase. Our concern is whether we will have the staff to serve the greater demand, and the room to accommodate the additional use. 